analysis of Antarctic politics with a consideration of the future course it is well worth reading. Unfortunately, being one of the Cambridge University Press Studies in Polar Research series, it is far too expensive, which is a pity as it has much of general interest. (R. K. Headland, Scott Polar Research Institute, University of Cambridge, Cambridge CB2 1ER UK.)

\section{ANTARCTICA: A PERSONAL VIEW}

SOUTH LIGHT: A JOURNEY TO ANTARCTICA. Parfitt, Michael. 1988. London, Bloomsbury.306 p, hard cover. ISBN 0-7475-0134-3. £14.95.

The author gives a personal account of a season with the United States Antarctic Research Program during a recent summer. This includes time aboard small and large vessels as well as periods ashore on several stations. A description of a landing near Mount Siple, a very rarely visited volcano, is included. Part of the narrative also describes King George Island and visits to several of its many national stations. The style is journalistic with much use of first and second person text in North American vernacular. Where appropriate this is interspersed with quotations from the heroic age of Antarctic exploration and descriptions from the discoverers (somewhat uncritically). Thus, in many areas, both contrasts with and similarities to the present are indicated. The work is written for a reader not very familiar with the Antarctic and includes many general details and descriptions of the continent. There is a comprehensive index but only one small map. (R. K. Headland, Scott Polar Research Institute, Cambridge.

\section{A POLAR JOURNEY RETRACED}

INTHE FOOTSTEPS OF SCOTT. R. MearandR. Swan. 1987. London, Jonathan Cape. 306 p, illustrated, hard cover. ISBN 0-224-01418-3. £14.95.

In the late 1970s and ' 80 s increasing numbers of small, privately-organized expeditions have entered the Antarctic cockpit, threatening an exclusiveness generally reserved for govemment operations of the Antarctic Treaty nations. It was inevitable that a private venture would be mounted on a scale that must bring it into conflict with operations of a treaty nation, and it is fitting that 'In the footsteps of Scott' was the expedition to do so.

This account of the expedition is written mainly by Mear, the man who shaped Swan's original dream from a polar plod to a bold, lightweight, alpine-style assault. Their early ideas and preparations are set against a background of mounting problems stemming from American unwillingness to support private ventures, and the concomitant escalation of their own logistics, which led the expedition to expand far beyond the original concept and almost caused Mear to withdraw. That the expedition sailed at all is a credit to everyone concerned, especially to Swan, whose monumental efforts are duly acknowledged.

The departure, voyage south and establishment of the shore base are briefly told and the narrative concentrates on the wintering party. Personality problems that appeared during the winter are discussed candidly, perhaps overstressing the tensionsg. Mear describes winter journeys to nearby Scott and McMurdo stations, a traverse of the Ross Island summits and a winter journey to Cape Crozier, repeating that of Scott's expedition. Much space is given to how the third member of the polar party was selected, and chapters covering the polar journey are as much psychological studies of the three team members as descriptions of the march itself; one wonders why they never came to blows. However, details of personality problems in such circumstances are rare, and for this reason Mear's account is valuable. Success at the pole is clouded by the loss of the expedition's ship, and with it loss of their hard-won independence.

Closing chapters document the deterioration of relations with NSF officials responsible for the US polar programme. It is difficult not to sympathize with an expedition that went to such lengths to make itself selfsufficient, only to be overtaken by events beyond its control, and hustled back to civilization by a less-thanfriendly US polar machine. It must be remembered that US official policy was made clear at the outset, and expedition members were naive to think that the Americans would jump at opportunities to help them. However, it is the manner, rather than the methods, that Mear questions in a forthright account.

Well illustrated, and largely free from typographic and other errors (though the Antarctic Treaty Organisation is mistakenly ascribed to the United Nations), this book endorses the spirit of adventure that well-run private expeditions can bring to the Antarctic. Their exploits, particularly in winter, contrast with the limitations imposed on personnel at nearby Scott and McMurdo stations. A highpoint for me is the delightfully underplayed account of Mear's solo winter ascent of MtErebus, a fourday trip that is surely unique in polar and mountaineering history. Beside it both the journey to Cape Crozier and the polar walk itself lack something important. Mear seems to suggest that private ventures of the future-and there will be many of them-might concentrate on more achievements of this kind. (Dan Hamer, Downlands, North Brook, Market Lavington, Devizes, Wilts SN10 4AN UK.)

\section{GROWING UP IN THE CANADIAN ARCTIC}

INUTT YOUTH-GROWTH AND CHANGE IN THE CANADIAN ARCTIC. Condon, Richard G. 1987. New Brunswick, NJ, Rutgers University Press. 252 p, maps, hard cover. ISBN 0-8135-1212-3. US $\$ 32$.

Inuit Youth is the first volume in a series entitled 'Adolescents in a changing world', an ambitious cross-cultural study on the effects of industrialization on the social behaviour of adolescents in seven traditional societies. The present volume reports the major results of Richard Condon's ethnographic research amongst the Copper Inuit at Holman Island, NWT Canada, in 1978-80 as part 